\title{
ANALISIS PREFERENSI KONSUMEN DALAM PENGGUNAAN SOCIAL MESSENGER DI KOTA BANDUNG TAHUN 2014 \\ (Studi Kasus : LINE, KAKAOTALK, WECHAT, WHATSAPP)
}

\author{
Noventi Ersa Putri ${ }^{1} \&$ Dadang Iskandar ${ }^{2}$ \\ ${ }^{1}$ Prodi Administrasi Bisnis, Fakultas Komunikasi dan Bisnis \\ ${ }^{2}$ Prodi Manajemen Bisnis Telekomunikasi \& Informatika, Fakultas \\ Ekonomi \& Bisnis, Universitas Telkom \\ ${ }^{2}$ email: dadang.iskandar1@gmail.com
}

\section{ABSTRAK}

Penelitian ini bertujuan untuk mengetahui "preferensi konsumen dalam penggunaan Social Messenger di kota Bandung". Metode yang digunakan dalam penelitian ini adalah metode eksploratif dan deskriptif, dengan menggunakan teknik Nonprobability sampling dan purposive sampling, dengan jumlah sampel 384 responden. Analisis data yang digunakan adalah Conjoint Analysis. Hasil penelitian ini menunjukan bahwa keseluruhan responden menjadikan atribut fasilitas fitur sebagai preferensi utama dalam memilih social messenger dengan nilai kepentingan tertinggi yaitu $48.361 \%$ dan level tertinggi yang menjadi preferensi fasilitas fitur adalah free chat dengan nilai kepentingan sebesar $0.603 \%$ dan atribut desain sesuai kebutuhan pelanggan sebagai atribut terendah dengan nilai kepentingan $15.256 \%$ dan level tertinggi yang menjadi preferensi desain sesuai kebutuhan pelanggan adalah memiliki tampilan yang menarik dengan nilai kepentingan sebesar $0.078 \%$.

Kata kunci : Preferensi, Conjoint Analisis 
Perkembangan teknologi informasi yang semakin maju dan sangat pesat memaksa secara tidak langsung manusia untuk tetap sadar akan keberadaan teknologi-teknologi baru yang ada di sekitarnya. Hampir setiap detik produk teknologi tercipta diseluruh belahan dunia. Manusia patut mengapresiasi perkembangan teknologi karena tentunya akan semakin membantu kehidupan manusia. Seiring dengan semakin pesatnya perkembangan teknologi, perkembangan internet pun meningkat. Indonesia sendiri adalah salah satu negara pengguna internet yang cukup tinggi di dunia, Sebuah survei yang diselenggarakan Asosiasi Penyelenggara Jasa Internet Indoneia (APJII) mengungkapkan bahwa jumlah pengguna internet di Indonesia tahun 2013 mencapai 82 juta pengguna, dan hal tersebut meningkat sebanyak 19 juta pengguna dari tahun 2012 yang mencatat adanya 63 juta pengguna internet di Indonesia.

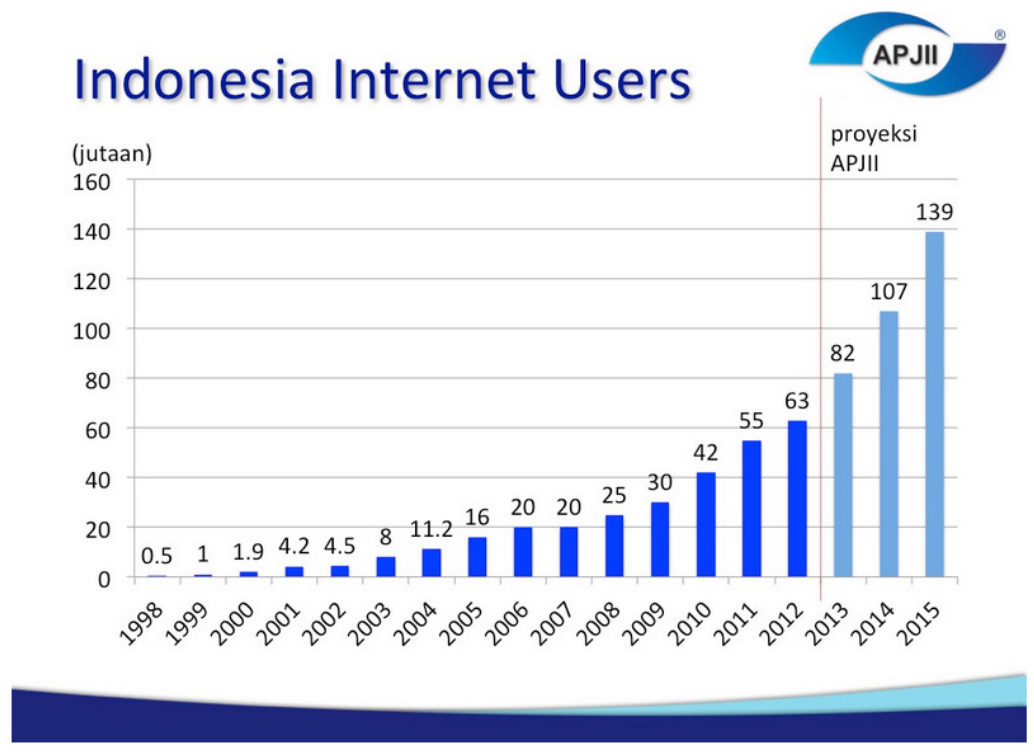

\section{Gambar 1.1 \\ Jumlah Pengguna Internet di Indonesia Sumber: http://www.apjii.or.id// 13 Februari 2014}

Berdasarkan Gambar 1.1, pengguna internet di Indonesia akan terus bertambah dan diproyeksikan pada tahun 2014 akan mencapai 107 Juta pengguna aktif dan pada tahun 2015 diproyeksikan akan terus bertambah yaitu mencapai 139 Juta pengguna aktif. Dewasa ini komunikasi tidak hanya dapat dilakukan secara fisik, tetapi dapat dilakukan dalam dunia maya dengan mediasi komputer dan smartphone dalam social network. Masyarakat telah mengenal adanya social messenger dimana chatting (obrolan) menjadi salah satu pilihan cara berkomunikasi. Sarana komunikasi tidak hanya bergantung pada telepon dan SMS saja. Saat ini telah hadir aplikasi messenger yang memungkinkan masyarakat untuk mengirim pesan secara instant kepada pengguna lainya. Messenger memiliki keunggulan dibandingkan dengan SMS. SMS hanya dapat mengirim pesan berupa teks saja. Akan tetapi messenger dapat mengirimkan pesan berupa teks, video, pesan suara, dan stiker.Aplikasi instant messenger telah menggeser kedudukan layanan pesan teks SMS. Menurut sebuah laporan dari lembaga analisis informa, pada tahun 2012 lalu akhirnya jumlah pesan yang dikirimkan melalui layanan instant messenger telah berhasil melampaui jumlah pesan yang dikirmkan melalui pesan teks SMS. Dengan angka 19 miliar pesan, untuk pertama kalinya jumlah pesan SMS yang berjumlah 17,6 miliar berhasil dilampaui oleh berbagai aplikasi instant messenger. (Sumber: www.trenologi.com, diakses pada tanggal 13 Februari 2014).

Pertumbuhan pengguna aplikasi instant messaging tersebut didukung dengan adanya berbagai aplikasi messenger yang ditawar pada masyarakat saat ini. 
JURNAL

MANAJEMEN

INDONESIA

Vol. 14. No. 2

Agustus 2014

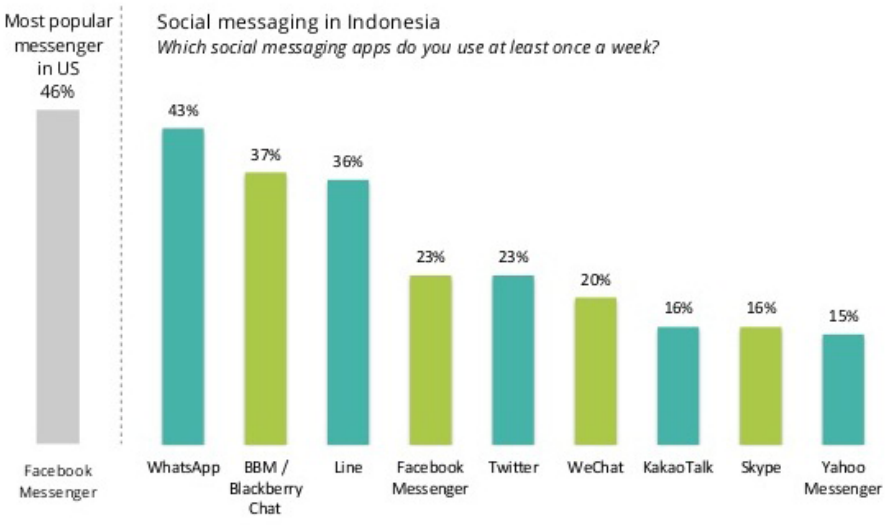

Gambar 1.2

Social Messaging di Indonesia

Sumber : www.trenologi.com

Berdasarkan Gambar 1.2 dapat dilihat bahwa terdapat beberapa penyedia layanan instant messaging di Indonesia diantaranya WhatsApp, Line, KakaoTalk, WeChat, BlackBerry Messenger, Facebook Messenger, Skype dan Yahoo Messenger. Menurut laporan dari sebuah lembaga riset pemasaran OnDevice bahwa aplikasi messenger yang sedang mengalami persaingan adalah LINE, WhatsApp, Wechat dan KakaoTalk. Persaingan tersebut ditunjukan dengan terus meningkatnya jumlah pengguna pada masing-masing aplikasi serta ditunjukan dengan inovasi yang terus dilakukan oleh perusahaan pengembang aplikasi messenger, hal tersebut terus dilakukan untuk menarik minat pengguna smartphone agar menggunakan aplikasi messenger yang mereka ciptakan. (Sumber : www.trenologi.com, diakses pada tanggal 13 Februari 2014). Menurut Kotler \& Keller (2012:170), perusahaan dapat mendesain dan mengaplikasiakan strategi yang dapat merangsang ketertarikan konsumen terhadap produk dengan memahami preferensi konsumen.

\section{Jumlah Pengguna \\ Social Messenger}

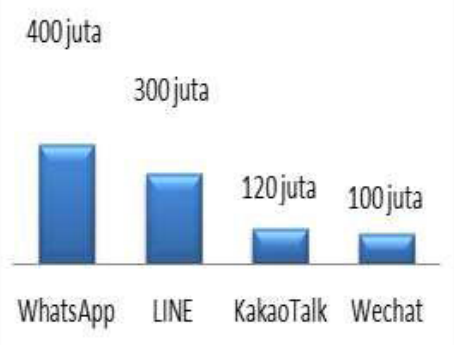

Gambar 1.3

Jumlah Pengguna Social Messenger

Sumber : www.techno.okezone.com. 
Berdasarkan Gambar 1.3 menjelaskan bahwa WhatsApp memiliki jumlah pengguna paling banyak yaitu 400 juta pengguna. Disusul dengan jumlah pengguna LINE yaitu 300 juta pengguna. Diikuti oleh KakaoTalk yang memiliki 120 juta pengguna. Kemudian Wechat yang memiliki 100 juta pengguna. Melihat tingginya jumlah pengguna social messenger saat ini diperkirakan angka tersebut akan terus naik pada tahun 2014. Berapa jumlah peningkatannya, hal itu tergantung pada usaha masing-masing. pengembang aplikasi instant messaging untuk melakukan pendekatan menarik kepada para penggunanya di dunia, termasuk indonesia.

Terpilihnya kota Bandung sebagai wilayah objek penelitian didasari karena Bandung merupakan kota dengan peringkat ketiga yang termasuk kedalam 7 kota yang memiliki penduduk paling banyak di Indonesia dengan jumlah penduduk sebesar 2.771.138 jiwa. (Sumber: www.ongsono.com, diakses pada tanggal 13 Februari 2014).

\section{Rumusan Masalah}

Masalah yang dapat di identifikasi dalam penelitian ini adalah Bagaimana prefrensi konsumen dalam penggunaan social messenger di kota Bandung dilihat dari tingkat kepentingan masing-masing atribut, serta menciptakan profil ideal yang merupakan hasil kombinasi atribut dan level dari social messenger yang paling diinginkan oleh konsumen.

\section{Tujuan Penelitian}

Tujuan dari penelitian ini adalah untuk mengetahui bagaimana preferensi konsumen dalam penggunaan social messenger di kota bandung dilihat dari tingkat kepentingan masing-masing atribut, serta menciptakan profil ideal yang merupakan hasil kombinasi atribut dan level dari social messenger yang paling diinginkan oleh konsumen.

\section{TINJAUAN PUSTAKA \\ Perilaku Konsumen}

Menurut Hawkins dan Mothersbaugh (2010: 6), perilaku konsumen adalah: "consumer behavior is the study of individuals, groups, or organization and the processes they use to select, secure, use and dispose of products, services, experiences, or ideas to satisfy needs and the impacts that these processes have an the consumer and the society" Artinya : perilaku konsumen adalah studi tentang individu, kelompok organisasii dan proses yang mereka gunakan untuk memilih, mengamankan, menggunakan dan membuang produk, jasa, pengalaman, atau ide dimana proses ini memiliki dampak terhadap konsumen dan dilingkungan masyarakat.

Menurut Schiffman dan Kanuk (2009:6) adalah studi perilaku konsumen terpusat pada cara individu mengambil keputusan untuk memanfaatkan sumber daya mereka yang tersedia (waktu, uang, usaha) guna membeli barang-barang yang berhubungan dengan konsumsi.

Konsumen dijadikan sebagai titik sentral perhatian dalam proses pemasaran. Mempelajari apa yang dibutuhkan dan diinginkan konsumen akan menuntun pemasar pada kebijakan pemasaran yang tepat dan efisien. Studi konsumen memberikan petunjuk untuk memperbaiki dan memperkenalkan produk atau jasa, menetapkan harga, perencanaan saluran, menyusun pesan, dan mengembangkan kegiatan pemasaran lain. Menurut Kotler dan Keller,(2012:161). Dalam model perilaku konsumen, proses dimulai dari stimuli marketing dan stimuli lainnya dari luar seperti ekonomi, teknologi, budaya, dan politik. Serangkaian stimuli tersebut akan dipengaruhi dan mempengaruhi psikologi dan karakteristik konsumen, yang selanjutnya berlanjut pada proses keputusan pembelian. Dalam proses keputusan pembelian, terdapat beberapa tahapan yang diawali dengan identifikasi masalah oleh konsumen mengenai apa yang dibutuhkan 
dan diperlukan konsumen. Tahapa selanjutnya dimana konsumen mencari informasi

\section{JURNAL}

MANAJEMEN

INDONESIA

Vol. 14. No. 2

Agustus 2014 mengenai serangkaian produk. Akan muncul beberapa alternatif produk yang akan dievaluasi. Dalam tahap evaluasi, konsumen akan membentuk preferensi atas serangkaian pilihan produk yang akhirnya menentukan keputusan pembelian.

\section{Keputusan Pembelian}

Menurut Kotler dan Armstrong (2008:181) dalam tahap evaluasi, konsumen menentukan peringkat merek dan membentuk niat pembelian. Pada umumnya, keputusan pembelian (purchase decision) konsumen adalah membeli merek yang paling disukai, tetapi dua faktor bisa berbeda antara niat pembelian dan keputusan pembelian. Faktor pertama adalah sikap orang lain. Keinginan dalam pembelian dapat dipengaruhi oleh faktor yang terdekat atau oleh orang yang telah dipercayai atau memiliki arti penting bagi si pembeli maka peluang si pembeli untuk mengikuti keinginannya sendiri berkurang. Faktor kedua adalah faktor situasional yang tidak diantisipasi. Konsumen mungkin membentuk niat pembelian berdasarkan faktor-faktor seperti pendapatan, harga dan manfaat produk yang diharapkan. Namun, kejadian tak terduga bisa mengubah niat pembelian (Kotler dan Armstrong, 2008:181).

\section{Perilaku Keputusan Pembelian}

Menurut Kotler dan Armstrong (2008:177) ada empat jenis perilaku pembelian konsumen berdasarkan tingkat keterlibatan pembeli dan tingkat diferensiasi merek, adalah sebagai berikut:

\section{Perilaku Pembelian Kompleks}

Perilaku pembelian konsumen dalam situasi yang ditentukan oleh keterlibatan konsumen yang tinggi dalam pembelian dan perbedaan yang dianggap signifikan antarmerek.

\section{Perilaku Pembelian Pengurangan Disonansi}

Perilaku pembelian konsumen dalam situasi yang mempunyai karakter keterlibatan tinggi tetapi hanya ada sedikit anggapan perbedaan antarmerek.

\section{Perilaku Pembelian Kebiasaan}

Perilaku pembelian konsumen dalam situasi yang mempunyai karakter keterlibatan konsumen rendah dan anggapan perbedaan merek sedikit.

\section{Perilaku Pembelian Mencari Keragaman}

Perilaku pembelian konsumen yang mempunyai karakter keterlibatan konsumen yang rendah tetapi dengan anggapan perbedaan merek yang signifikan

\section{Pengambilan Keputusan Konsumen}

Dalam mengonsumsi suatu produk ataupun service ada tahapan yang dilakukan oleh konsumen, mengetahui tentang tahapan ini dapat membantu pemasar ataupun perusahaan untuk mengerti perilaku konsumen. Kotler dan Keller, (2009:184) Pada dasarnya, proses keputusan pembelian yang dilakukan oleh konsumen dibagi menjadi lima tahapan seperti yang dinyatakan Kotler \& Armstrong (2008:179), yaitu dimulai dari tahap pengenalan kebutuhan, pencarian informasi, evaluasi alternatif, keputusan pembelian, dan perilaku pasca pembelian.

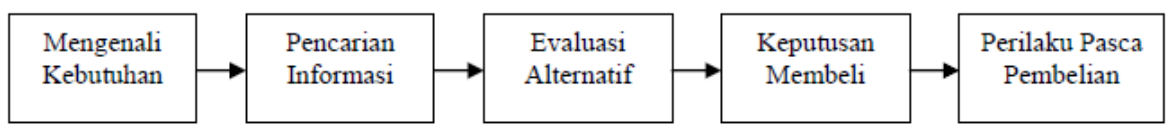

Gambar 2.1

Proses Pengambilan Keputusan

Sumber : Kotler dan Armstrong (2008:179) 
Proses pembelian dimulai dengan pengenalan kebutuhan (need recognition) pembeli menyadari suatu masalah atau kebutuhan. Kebutuhan dapat dipicu oleh rangsangan internal ketika salah satu kebutuhan normal seseorang seperti rasa lapar, haus, seks timbul pada tingkat yang cukup tinggi sehingga menjadi dorongan. Kebutuhan juga bisa dipicu oleh rangsangan eksternal.

\section{JURNAL \\ MANAJEMEN \\ INDONESIA}

Vol. 14. No. 2

Agustus 2014

\section{Pencarian Informasi}

Konsumen yang tertarik mungkin mencari lebih banyak informasi atau mungkin tidak. Jika dorongan konsumen itu kuat dan produk yang memuaskan ada didekat konsumen itu, konsumen mungkin akan membelinya kemudian. Jika tidak, konsumen bisa menyimpan kebutuhan itu dalam ingatannya atau melakukan pencarian informasi yang berhubungan dengan kebutuhannya.

\section{Evaluasi Alternatif}

Merupakan tahap proses keputusan pembeli di mana konsumen menggunakan informasi untuk mengevaluasi merek alternatif dalam sekelompok pilihan atau bagaimana konsumen memproses informasi untuk sampai pada pilihan merek. Sayangnya, konsumen tidak menggunakan proses evaluasi yang sederhana dan tunggal dalam semua situasi pembelian. Sebagai gantinya, beberapa proses evaluasi dilaksanakan.

\section{Keputusan Pembelian}

Dalam tahap evaluasi, konsumen menentukan peringkat merek dan membentuk niat pembelian. Pada umumnya, keputusan pembelian (purchase decision) konsumen adalah membeli merek yang paling disukai, tetapi dua faktor bisa berada antara niat pembelian dan keputusan pembelian. Faktor pertama adalah sikap orang lain. Faktor kedua adalah faktor situasional yang tidak diharapkan.

\section{Perilaku Pasca pembelian}

Tahap proses keputusan pembeli di mana konsumen mengambil tindakan selanjutnya setelah pembelian, berdasarkan kepuasan atau ketidakpuasan mereka. Semakin besar kesenjangan antara ekspektasi dan kinerja, semakin besar pula ketidakpuasan konsumen. Hal ini menunjukkan bahwa penjual hanya boleh menjanjikan apa yang dapat diberikan mereknya sehingga pembeli terpuaskan. Bagaimana mengevaluasi keluhan konsumen dan harus dapat mengatasi keluhan tersebut dengan baik.

\section{Evaluasi altenatif dan seleksi}

Seberapa rumit proses evaluasi alternatif yang dilakukan konsumen sangat tergantung kepada model pengambilan keputusan yang dijalani konsumen. Informasi yang diperoleh, selanjutnya di proses untuk mendpatkan keputusan atau pertimbangan nilai akan suatu produk, dan akan menghasilkan beberapa atribut yang akan muncul, setelah itu baru di beri bobot dari berbagai alternatif. Hawkins dan Motherbough (2010:549) mengilustrasikan evaluasi alternatif dan seleksi pemilihan sebuah produk sebelum melakukan keputusan pembelian. Evaluasi alternatif yang dijelaskan oleh Hawkins dan Motherbough terbagi menjadi tiga bagia yaitu kriteria evaluasi, kriteria penting dan alternatif yang dianggap. Setiap konsumen mempunyai pandangan yang berbeda dari ketiga evaluasi yang diberikan tersebut.

Tahapan ketiga dari proes pengambilan keputusan konsumen adalah melakukan evaluasi alternatif. Untuk pertama, gambaran umum diatas merupakan proses konsumen untuk memakai atau memilih dan membandingkan produk alternatif yang ada. Kemudian mendeskripsikan keadaan dan karakteristik kriteria evaluasi (misal : keuntungan dari memilih produk tersebut). Setelah memeriksa kriteria evaluasi, kriteria penting, dan al- 


\section{JURNAL \\ MANAJEMEN \\ INDONESIA}

Vol. 14. No. 2

Agustus 2014 ternatif yang tersedia. Konsumen akan fokus melihat kemampuan menilai kinerja dari sebuah produk. Terakhir, memeriksa aturan keputusan yang akan diterapkan oleh konsumen tersebut untuk memilih satu alternatif yang mereka anggap baik dan ciptakan kepuasan bagi konsumen itu sendiri. Beberapa konsep dasar akan membantu memahami proses evaluasi konsumen, pertama, konsumen berusaha memenuhi kebutuhan. Kedua, konsumen mencari manfaat tertentu dari solusi produk. Ketiga, konsumen memandang masing-masing produk sebagai sekumpulan atribut dengan kemampuan yang berbeda-beda dalam memberikan manfaat yang digunakan untuk memuaskan kebutuhan itu, atribut yang diminati oleh pembeli berbeda-beda bergantung jenis produknya.

\section{Preferensi}

Preferensi konsumen merupakan suatu sikap konsumen terhadap satu pilihan merek produk yang terbentuk melalui evaluasi atas berbagai macam merek dalam berbagai pilihan yang tersedia. Kotler dan Keller, (2009:181). Sedangkan menurut Frank (2011:63), preferensi adalah proses merengking seluruh hal yang dapat dikonsumsi dengan tujuan memperoleh preferensi atas suatu produk maupun jasa. Menurut Kotler dan Keller (2007:210), ada beberapa tahap yang akan dilalui oleh konsumen sehingga menggambarkan rasa kepuasannya terhadap suatu produk. Menurut Schiffman dan Kanuk (2000:146), sifat stimulus konsumen meliputi banyak variabel yang akan mempengaruhi persepsi konsumen, seperti keadaan produk, ciri fisiknya, rancangan kemasan, merk, iklan cetak dan iklan tv. Diskriminasi stimulus adalah kemampuan konsumen untuk melakukan pembedaan diantara stimuli yang serupa merupakan dasar bagi strategi pengaturan posisi yang berusaha mengembangkan citra yang khas produk tertentu kedalam pikiran konsumen. Menurut Schiffman dan Kanuk (2000:181), pengkondisian berarti seperti respon terhadap situasi yang terjadi melalui pemaparan yang berulang-ulang.

Preferensi konsumen muncul dalam tahap evaluasi alternatif dalam proses keputusan pembelian, dimana dalam tahap tersebut konsumen dihadapkan dengan berbagai macam pilihan produk maupun jasa dengan berbagai macam atribut yang berbeda-beda. Oleh karena itu, dapat disimpulkan bahwa preferensi adalah suatu pilihan yang diambil dan dipilih konsumen dari berbagai macam pilihan yang tersedia. Didalam tahap ini dapat dilihat pada saat kapan tahap preferensi tersebut hadir pada konsumen, tahapan tersebut dapat dilihat pada gambar 2.3 dibawah ini.

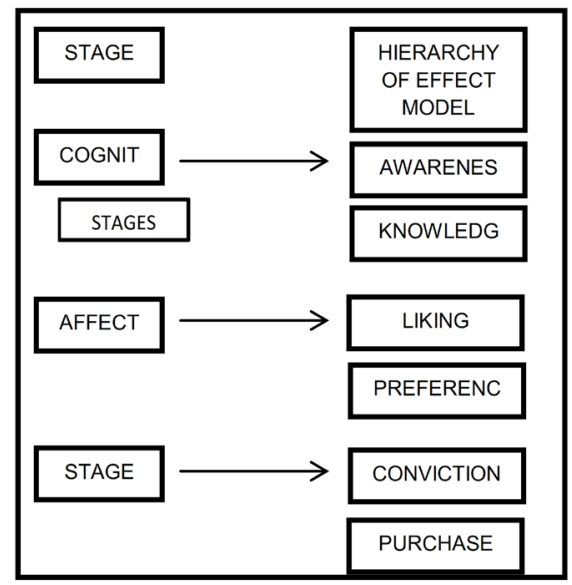

Gambar 2.3

Model Hierarchi of Effect

Sumber : Kotler dan Keller (2007:210) 
Pada gambar diatas dapat dilihat bahwa terdapat enam langkah dalam model hierarchy of effect yaitu :

1. Awareness/kesadaran, tahap ini adalah tahap dimana konsumen menyadari adanya suatu produk baik itu berupa barang atau jasa.

2. Knowledge/pengetahuan : di dalam tahap ini konsuen sudah mengenal produk dan mengerti tentang produk yang berupa barang atau jasa tersebut.

3. Liking/menyukai : tahap ini adalah tahap dimana konsumen mulai menyukai produk tersebut yang berupa barang atau jasa yang ditawarkan.

4. Preference/memilih : tahap ini adalah tahap dimana konsumen mulai lebih melilih produk tersebut dibandingkan produk-produk lainya.

5. Conviction/intention to buy/keinginan untuk membeli : tahap ini konsumen mempunyai keinginan dan memutuskan untuk membeli produk.

6.Purchase/membeli : pada tahap ini adalah tahap dimana konsumen dapat dikatakan sebagai konsumen yang loyal terhadap sebuah produk, sehingga konsumen tersebut tidak ragu lagi untuk membeli produk tersebut tanpa adanya pertimbangan yang banyak.

Tahap preferensi yang dimiliki oleh konsumen terhadap sebuah produk, adalah awal dari tahap loyalitas konsumen terhadap produk tersebut. Sehingga perusahaan harus mempelajari bagaimana cara menimbulkan rasa preferensi tersebut di dalam diri.

Tahap preferensi tersebut dapat perilaku konsumen tersebut, dengan mempengaruhi dan memanipulasi dari konsumen yang mereka lalui. pengusaha untuk mengenali kebutuhan konsumen agar diperoleh produk dengan orientasi pasar, didasarkan pada tingkat preferensi konsumen bagi tiap-tiap atribut produk. Preferensi juga dapat digunakan untuk mengidentifikasi segmen preferensi

Sumber : Kotler dan Keller (2007:210)

Menurut Kotler dan Keller (2007:294), ada tiga pola preferensi yang dapat terbentuk :

1.Preferensi Homogen Menunjukan suatu pasar dimana semua pelanggan secara kasar memiliki preferensi yang sama.

2.Preferensi Tersebar Yang menunjukan bahwa pelanggan sangat berbeda dalam preferensi mereka.

3.Preferensi kelompok-kelompok Dimana pasar menunjukan kelompok- kelompok preferensi yang berbeda- beda.

Dengan memahami preferensi konsumen, perusahaan dapat merancang strategi yang tepat untuk merespon ekspektasi konsumen dan menjadikan strategi differensiasi sebuah perusahaan tersebut dengan pesaingnya, Menurut Kotler dan Keller (2007:296) ada beberapa langkah yang harus dilalui sampai konsumen membentuk preferensi :

1.Diasumsikan bahwa konsumen melihat produk sebagai sekumpulan atribut. Konsumen yang berbeda memiliki atribut yang berbeda mengenai suatu produk yang relevan.

2.Tingkat kepentingan atribut berbeda-beda sesuai dengan kebutuhan dan keinginan masing-masing. Konsumen memiliki penekanan yang berbeda-beda dalam menilai atribut apa yang paling penting. Konsumen yang daya belinya besar akan mementingkan atribut harga yang paling utama.

3.Konsumen mengembangkan sejumlah kepercayaan tentang letak produk pada setiap atribut.

4. Tingkat kepuasan konsumen terhadap produk akan beragam sesuai dengan perbedaan atribut.

5.Konsumen akan sampai pada sikap terhadap merek yang berbeda melalui prosedur evaluasi. 


\section{JURNAL}

MANAJEMEN

INDONESIA

Vol. 14. No. 2

Agustus 2014

\section{Pengertian Produk \& Klasifikasi Produk}

Produk merupakan output dari apa yang diproduksi oleh perusahaan yang ditawarkan kepada masyarakat, seperti yang dinyatakan oleh Kotler \& Armstrong (2008:266), bahwa produk merupakan semua hal yang dapat ditawarkan kepada pasar untuk menarik perhatian, akuisisi, penggunaan, atau konsumsi yang dapat memuaskan suatu keinginan atau kebutuhan. Produk merupakan hasil kreatifitas dan kinerja perusahaan yang pada akhirnya produk inilah yang menjadi sarana konsumen untuk menilai dan mempunyai pandangan atas perusahaan dilihat dari produk yang diciptakannya.

Kotler \& Armstrong (2008:269) mengklasifikasikan produk kedalam dua kelompok besar berdasarkan tipe konsumen yang menggunakannya, yaitu produk konsumen dan produk industri. Produk konsumen adalah produk yang dikonsumsi maupun dibeli oleh konsumen akhir demi keperluan konsumsi pribadi, sedangkan produk Industri adalah produk yang dibeli oleh individu dan organisasi untuk pemrosesan lebih lanjut atau untuk digunakan dalam menjalankan bisnis. Baik produk konsumen maupun produk industri juga masing-masing terdapat beberapa kelompok, yaitu :

a. Produk Konsumen

1. Produk kebutuhan sehari-hari

Merupakan suatu produk konsumen yang biasanya sering dan segera dibeli pelanggan, dengan usaha pembandingan dan pembelian yang minimum.

2. Produk belanja

Merupakan barang konsumen dimana pelanggan, dalam proses pemilihan dan pembelian, secara karakteristik membandingkan produk tersebut berdasarkan kecocokan, kualitas, harga, dan gaya.

3. Produk Khusus

Merupakan produk konsumen dengan karakteristik unik atau identifikasi merek dimana sekelompok pembeli signifikan bersedia melakukan usaha pembelian khusus.

4. Produk yang tak dicari

Merupakan produk konsumen yang tidak dikenal konsumen atau mungkin dikenal konsumen tetapi biasanya konsumen tidak pernah berpikir untuk membelinya.

b. Produk Industri

1. Bahan dan suku cadang

Bahan dan suku cadang mencakup bahan mentah serta bahan dan suku cadang manufaktur.

2. Barang-barang modal

Merupakan produk industri yang membantu produksi atau operasi pembeli, termasuk peralatan instalasi dan aksesori.

3. Persediaan dan jasa

Persediaan mencakup persediaan operasi serta barang perbaikan dan pemeliharaan, sedangkan persediaan merupakan produk kebutuhan sehari- hari dalam bidang industri karena persediaan ini biasanya dibeli dengan usaha atau perbandingan minimum.

\section{Atribut Produk}

Menurut Kotler \& Armstrong,(2008:272) atribut produk merupakan suatu komunikasi atas manfaat dari hasil pengembangan suatu produk atau jasa yang akan ditawarkan produk atau jasa tersebut. Atribut produk tersebut meliputi kualitas, fitur, serta gaya dan desain.

1.Kualitas Produk

Kualitas produk adalah salah satu sarana positioning bagi pemasar, kualitas produk ini erat kaitannya dengan nilai dan kepuasan pelanggan, karena kualitas produk menimbulkan dampak secara langsung bagi kinerja produk atau jasa yang 
dapat dirasakan oleh konsumen. Kualitas produk mempunyai dua dimensi utama, yaitu tingkat dan konsistensi, tingkat disini berarti bahwa perusahaan pada awalnya harus menciptakan tingkat kualitas produk, yang selanjutnya dipergunakan bagi positioning produk tersebut, selanjutnya, konsistensi terhadap tingkat kualitas tersebut atas suatu produk harus dipertahankan agar konsumen dapat merasakan konsistensi kualitas sesuai dengan yang diharapkan.

2.Fitur Produk

Fitur merupakan sarana kompetitif untuk mendeferensiasikan produk perusahaan dari produk pesaing. Sebuah produk dapat ditawarkan dengan berbagai fitur, baik fitur lama, maupun fitur yang baru. Menjadi produsen pertama yang memperkenalkan fitur baru yang bernilai adalah salah satu cara paling efektif untuk bersaing. Sedangkan menurut Kotler dan Keller (2009:8). Sebagian besar produk dapat ditawarkan dengan memvariasikan fitur yang melengkapi fungsi dasar mereka.

3. Gaya dan Desain Produk

Desain adalah konsep yang lebih besar dari pada gaya yang hanya menggambarkan penampilan produk dan merupakan jantung dari suatu produk dan tidak hanya sekedar kulit luar. Desain yang baik dimulai dengan pemahaman mendalam tentang kebutuhan pelanggan. Lebih dari sekedar menciptakan atribut produk maupun jasa, tapi desain melibatkan pembetukan pengalaman pemakaian produk bagi pelanggan. Sedangkan menurut Kotler dan Keller (2009:10). Desain adalah totalitas fitur yang mempengaruhi tampilan, rasa dan fungsi produk berdasarkan kebutuhan kebutuhan inti dari produk yang akan dibeli konsumen.

\section{Tingkatan Produk}

Menurut Kotler dan Keller (2009:231), terdapat lima golongan produk dalam proses perencanaan pengembangan produk. Kelima golongan produk tersebut adalah : a. Produk Inti (Core Product)

Merupakan inti dari apa yang sebenarnya dibutuhkan dari suatu produk. Pemasar harus mengetahui kebutuhan inti dari produk yang akan dibeli konsumen.

b.Fisik Produk (Basic Product)

Merupakan karakteristik dari suatu produk yang meliputi tingkat kualitas, model, merek, kemasan, serta ciri suatu produk.

c.Produk yang diharapkan (Expected Product)

Merupakan sekumpulan atribut dan level yang diharapkan konsumen atas suatu produk.

d.Produk Tambahan (Augmented Product)

Merupakan manfaat tambahan yang terdapat pada suatu produk yang diberikan oleh perusahaan.

e.Produk Potensial (Potential Product)

Merupakan konsep produk masa datang yang menawarkan berbagai fitur baru.

Berdasarkan teori-teori tersebut, maka dapat digambarkan kerangka pemikiran pada penelitian ini adalah sebagai berikut:
JURNAL

MANAJEMEN

INDONESIA

Vol. 14. No. 2

Agustus 2014 
JURNAL

MANAJEMEN

INDONESIA

Vol. 14. No. 2

Agustus 2014

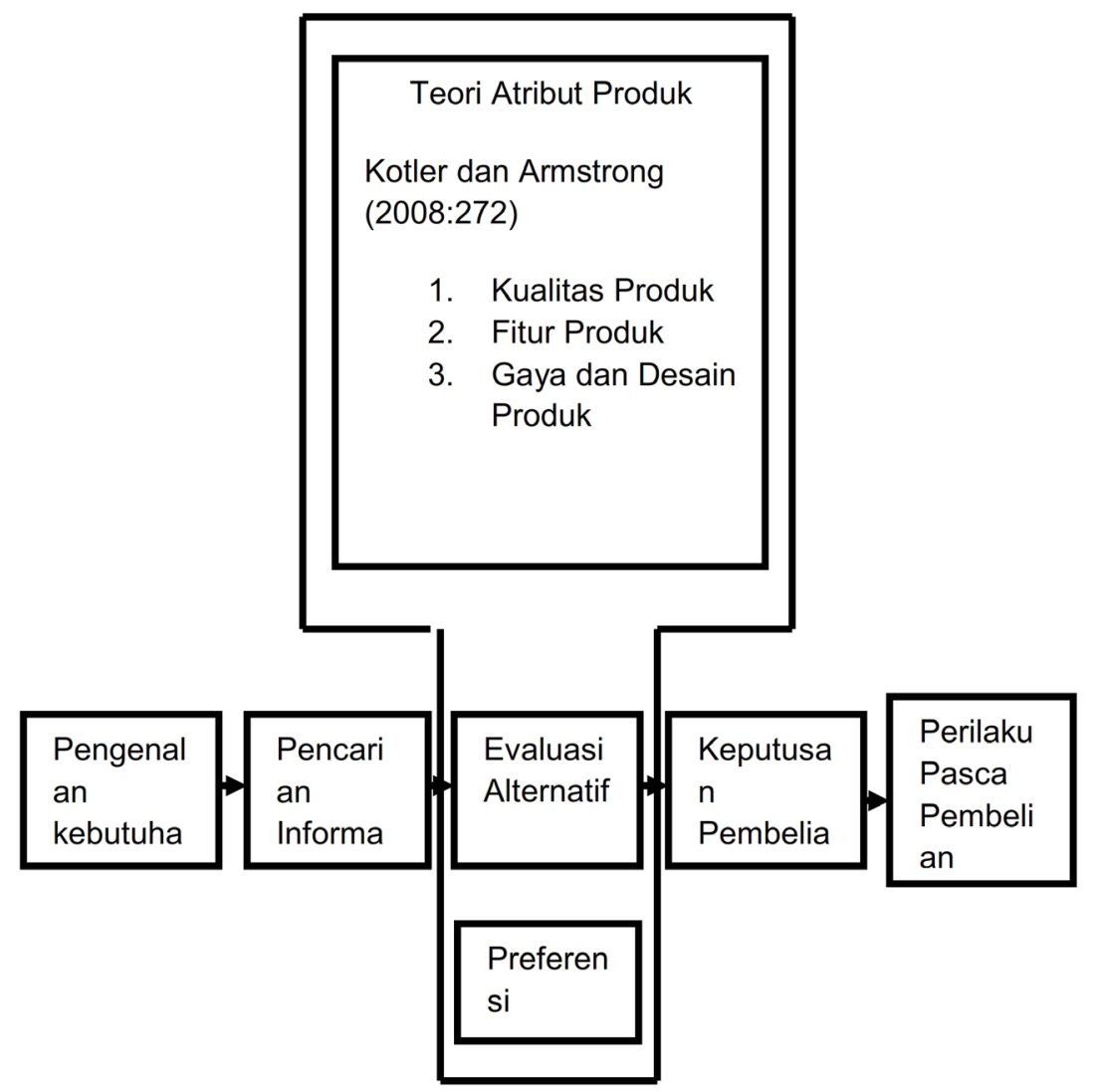

Gambar 2.4

Kerangka Pemikiran

Sumber: Olahan Penulis

\section{METODE PENELITIAN}

Metode penelitian yang digunakan dalam penelitian ini adalah metode eksploratori dan deskriptif. Menurut Arikunto (2010:32), metode eksploratori adalah metode penelitian yang bertujuan untuk menggali suatu informasi. Dengan kata lain, penelitian ini bertujuan untuk menggali informasi mengenai preferensi konsumen terhadap penggunaan social messenger di kota Bandung. Menurut Sedarmayanti dan Hidayat (2011:33), metode deskriptif adalah suatu metode pencarian fakta suatu sekelompok manusia, suatu obyek, suatu kondisi, suatu sistem pemikiran ataupun suatu peristiwa pada masa sekarang dengan interpretasi yang tepat. Sedangkan menurut Sekaran dan Bougie (2010:105). Metode deskriptif adalah suatu metode yang digunakan untuk memastikan dan mendeskripsikan karakteristik dari suatu variabel dalam suatu situasi. Metode deskriptif pada umumnya bertujuan untuk memberikan suatu profil kepada peneliti atau untuk mendeskripsikan suatu aspek dari suatu fenomena yang terjadi pada individu, organisasi, ataupun perspektif lainnya. Dalam penelitian ini penulis tidak membahas dan tidak bertujuan untuk membuktikan hipotesis penelitian. diperoleh sampel dalam penelitian ini minimal 97 dan dibulatkan menjadi 100 responden.

\section{Variabel Operasional dan Skala Pengukuran}

Menurut Sugiyono (2012:38) Variabel penelitian adalah suatu atribut atau sifat atau nilai dari orang, objek atau kegiatan yang mempunyai variasi tertentu yang ditetapkan oleh peneliti untuk dipelajari dan ditarik kesimpulannya. Sedangkan menurut Zikmund. (2010:119), variabel adalah sesuatu yang bervariasi atau berubah dari satu contoh ke contoh lainnya. Variabel biasanya menunjukan perbedaan pada nilai, misalnya besaran, kekuatan, atau arah. Dalam penelitian yang menggunakan analisis conjoint, istilah variabel disebut sebagai atribut, dan sub-atribut disebut level. Menurut Hair et al (2010:282), dalam penentuan level haruslah melihat kondisi realita yang sebenarnya, 
dan level yang tidak berhubungan dan tidak realistis haruslah di eliminasi, oleh karena itu, penentuan level dalam penelitian ini telah disesuaikan dengan kondisi yang sebenarnya. Atribut yang digunakan dalam penelitian preferensi mengenai social messenger ini, diambil dari teori atribut produk yang dikemukakan oleh Kotler dan Armstrong, (2008:272). Atribut tersebut adalah kualitas produk, fitur produk, gaya dan desain produk. Pada Tabel 3.1 akan dijelaskan lebih rinci mengenai variabel yang digunakan.

\begin{tabular}{|c|c|c|}
\hline Atribut & Taraf & Level \\
\hline $\begin{array}{l}\text { Tingkat } \\
\text { Kualitas } \\
\text { Produk }\end{array}$ & $\begin{array}{l}1 \\
2 \\
3\end{array}$ & $\begin{array}{l}\text { Produk yang memiliki layanan yang lengkap } \\
\text { dan berkualitas. } \\
\text { Produk yang mengirimkan pesan dengan cepat } \\
\text { Produk yang dapat digunakan dengan mudah }\end{array}$ \\
\hline $\begin{array}{l}\text { Fasilitas } \\
\text { Fitur }\end{array}$ & $\begin{array}{l}1 \\
2 \\
3 \\
4 \\
5 \\
6\end{array}$ & $\begin{array}{l}\text { Free Chat } \\
\text { Free Call } \\
\text { Video Call } \\
\text { Voice Call } \\
\text { Sticker Grup } \\
\text { Chat }\end{array}$ \\
\hline $\begin{array}{l}\text { Fitur } \\
\text { Tambahan }\end{array}$ & $\begin{array}{l}1 \\
2 \\
3\end{array}$ & $\begin{array}{l}\text { Game } \\
\text { Official Accounts } \\
\text { Sticker Shop }\end{array}$ \\
\hline $\begin{array}{l}\text { Desain sesuai dengan } \\
\text { kebutuhan pelanggan }\end{array}$ & $\begin{array}{l}1 \\
2 \\
3\end{array}$ & $\begin{array}{l}\text { Tema yang dapat diganti sesuai keinginan } \\
\text { Background yang dapat diganti sesuai } \\
\text { keinginan } \\
\text { Memiliki tampilan yang menarik }\end{array}$ \\
\hline
\end{tabular}

\section{Skala Pengukuran}

Sugiyono (2012:92), Skala pengukuran merupakan kesepakatan yang digunakan sebagai acuan untuk menentukan panjang pendeknya interval yang ada dalam alat ukur. Skala pengukuran yang digunakan. Sedangkan menurut Sekaran dan Bougie, (2010:141) Skala adalah suatu alat ataupun suatu mekanisme dimana dipakai oleh individu untuk membedakan variabel satu dengan yang lainnya yang digunakan dalam penelitian. Dalam penelitian ini, skala yang digunakan adalah skala nominal dan ordinal. Martono (2010:54) Skala nominal adalah skala yang digunakan untuk mengklasifikasikan suatu objek maupun kejadian kedalam suatu kelompok tertentu sehingga dapat diamati kesamaan maupun perbedaan atas ciri-ciri tertentu.Sedangkan menurut Gozali (2013:3), Skala nominal merupakan skala pengukuran yang menyatakan kategori, atau kelompok dari suatu subyek. Dalam penelitian ini, skala nominal digunakan dalam pertanyaan tentang profil responden yang terdapat dalam kuesioner. Menurut Rangkuti (2011:65), skala ordinal (ordinal scale) adalah Skala yang bertujuan untuk membedakan antara kategori-kategori dalam satu variabel dengan asumsi bahwa ada urutan atau tingkatan skala. Angka-angka ordinal lebih menunjukkan urutan peringkat. Sedangkan menurut Sekaran dan Bougie, (2010:142), Skala ordinal merupakan skala yang tidak hanya mengelompokkan suatu variabel yang ada, namun juga memberikan urutan (ranking) antar kategori tersebut. Dalam penelitian ini, skala ordinal digunakan dalam pertanyaan yang mengacu kepada preferensi responden. 


\section{Populasi dan Sampel}

JURNAL

MANAJEMEN

INDONESIA

Vol. 14. No. 2

Agustus 2014
Menurut Zikmund (2010:390), populasi adalah seluruh kumpulan dari elemen-elemen yang mampu memberikan sebuah data dari sebuah penelitian. Menurut Sedarmayanti (2011:121) Populasi adalah himpunan keseluruhan karakteristik dari objek yang diteliti. Sedangkan menurut Sugiyono,(2012:80) populasi adalah wilayah generalisasi yang terdiri atas obyek atau subyek yang mempunyai kualitas dan karakteristik tertentu yang ditetapkan oleh peneliti untuk dipelajari dan kemudian ditarik kesimpulannya.

Pada penelitian ini, populasi yang dipakai yaitu pengguna social messenger yang berada di kota Bandung.Menurut Sedarmayanti (2011:124) Sampel adalah kelompok kecil yang diamati dan merupakan bagian dari populasi sehingga sifat dan karakteristik populasi juga dimiliki oleh sampel. Sedangkan menurut Sugiyono (2012:81) Sampel adalah bagian dari jumlah dan karakteristik yang dimiliki oleh populasi.Bila populasi besar, dan penelitian tidak mungkin mempelajari semua yang ada pada populasi, misalnya karena keterbatasan dana, tenaga dan waktu, maka penelitian dapat menggunakan sampel yang diambil dari populasi itu. Dikarenakan populasi tidak diketahui jumlahnya, maka untuk menentukan jumlah sampel yang akan diteliti penulis menggunakan persamaan Bernoulli berikut ini :

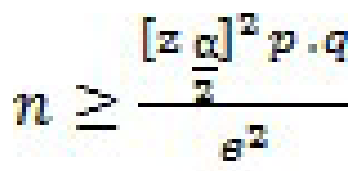

Keterangan :

$\mathrm{n}=$ jumlah sampel minimum

$\mathrm{Z}=$ Kuadrat dari confidence interval

$\alpha / 2=$ Tingkat kepercayaan yang masih

dapat diterima $(95 \%=1,96)$

$\mathrm{e}=$ Tingkat kesalahan yang masih diterima

$\mathrm{p}=$ Perkiraan proporsi keberhasilan

$\mathrm{q}=$ Perkiraan proporsi kegagalan/ 1-p

Penelitian ini menggunakan tingkat kepercayaan 95\% sehingga diperoleh nilai $\mathrm{Z}=1,96$. Tingkat kesalahan ditentukan sebesar 5\%. Sedangkan probabilitas kuesioner benar (diterima) atau ditolak (salah) masing-masing 0,5. Berdasarkan tingkat ketelitian, tingkat kepercayaan,nilai Z, tingkat kesalahan dan probabilitas diterima yang telah ditentukan maka selanjutnya dimasukan kedalam persamaan rumus bernoulli :

$$
n \geq \frac{(1,96)^{2} 0,5 \times 0,5}{(0,05)^{2}}=384
$$


Sehingga jumlah sampel yang diambil $n>384$ sampel. Dan dalam penelitian ini diambil sampel sebanyak 400 responden. Menurut Sugiyono,(2012:81) Teknik sampling merupakan teknik pengambilan sampel. Pengambilan sampel dalam penelitian ini menggunakan metode nonprobability sampling yaitu pemilihan sampel dengan memberi peluang yang tidak sama kepada unsur yang berkaitan untuk menjadi sampel. Selanjutnya teknik sampling yang digunakan adalah Purposive Sampling. Menurut Martono (2010:70), Purposive Sampling merupakan suatu teknik penentuan sampel dimana peneliti melihat suatu pertimbangan tertentu, dalam penelitian ini, peneliti memilih sendiri responden yang akan dijadikan sampel yang peneliti anggap cocok, benar-benar mengetahui, atau memiliki kompetensi dengan peneltian ini. Di dalam penelitian ini, penulis memilih konsumen ataupun orang yang pernah menggunakan social messenger di kota Bandung.

\section{HASIL PENELITIAN DAN ANALISIS}

Tingkat kepentingan masing-masing atribut dari hasil olah data analisa konjoin dengan menggunakan SPSS v.20.didapatkan nilai kepentingan keseluruhan dari masing-masing atribut.

\begin{tabular}{|c|l|}
\hline Importance & \multicolumn{1}{c|}{ Atribut } \\
\hline 17.731 & $\begin{array}{l}\text { Tingkat Kualitas } \\
\text { Produk }\end{array}$ \\
\hline 48.361 & Fasilitas Fitur \\
\hline 18.552 & Fitur Tambahan \\
\hline 15.256 & $\begin{array}{l}\text { Desain Sesuai } \\
\text { Kebutuhan Pelanggan }\end{array}$ \\
\hline \multicolumn{2}{|l|}{ Sumber: pengolahan data kuesioner }
\end{tabular}

Dari tabel di atas menunjukan bahwa atribut fasilitas fitur merupakan atribut yang mempunya nilai kepentingan tertinggi, yaitu mencapai 48.361. selanjutnya adalah atribut fitur tambahan dengan nilai kepentingan 18.552. atribut tingkat kualitas produk dengan nilai kepentingan 17.731. dan yang terendah adalah atribut desain sesuai kebutuhan pelanggan dengan nilai kepentingan 15.256.

\begin{tabular}{|c|c|c|}
\hline \multicolumn{3}{|c|}{$\begin{array}{l}\text { IMPORTANCE VALUE DAN NILAI } \\
\text { UTILITY KESELURUHAN }\end{array}$} \\
\hline Atribut & Utility & Level \\
\hline \multirow{3}{*}{$\begin{array}{l}\text { Tingkat } \\
\text { Kualitas } \\
\text { Produk }\end{array}$} & -0.094 & $\begin{array}{l}\text { Produk yang memiliki } \\
\text { layanan lengkap dan } \\
\text { berkualitas }\end{array}$ \\
\hline & -0.106 & $\begin{array}{l}\text { Produk yang } \\
\text { mengirimkan pesan } \\
\text { dengan cepat }\end{array}$ \\
\hline & 0.200 & $\begin{array}{l}\text { Produk yang dapat } \\
\text { digunakan dengan } \\
\text { mudah }\end{array}$ \\
\hline \multirow{5}{*}{$\begin{array}{l}\text { Fasilitas } \\
\text { Fitur }\end{array}$} & 0.603 & Free Chat \\
\hline & 0.154 & Free Call \\
\hline & 0.231 & Video Call \\
\hline & -0.450 & Voice Call \\
\hline & -0.538 & Grup Chat \\
\hline \multirow{3}{*}{$\begin{array}{l}\text { Fitur } \\
\text { Tambahan }\end{array}$} & 0.130 & Game \\
\hline & $-0,058$ & Official Accounts \\
\hline & -0.072 & Sticker Shop \\
\hline \multirow{3}{*}{$\begin{array}{l}\text { Desain } \\
\text { Sesuai } \\
\text { Kebutuhan } \\
\text { Pelanggan }\end{array}$} & -0.128 & $\begin{array}{l}\text { Tema yang dapat } \\
\text { diganti sesuai keinginan }\end{array}$ \\
\hline & -0.050 & $\begin{array}{l}\text { Background yang dapat } \\
\text { diganti sesuai keinginan }\end{array}$ \\
\hline & 0.078 & $\begin{array}{l}\text { Memiliki Tampilan yang } \\
\text { Menarik }\end{array}$ \\
\hline
\end{tabular}


JURNAL

MANAJEMEN

INDONESIA

Vol. 14. No. 2

Agustus 2014
Setelah melihat preferensi yang diinginkan konsumen mengenai social messenger, maka dapat dibentuk profil ideal yang diinginkan oleh konsumen secara keseluruhan.

\begin{tabular}{|l|l|}
\hline \multicolumn{1}{|c|}{ Atribut } & \multicolumn{1}{c|}{ Level } \\
\hline $\begin{array}{l}\text { Tingkat Kualitas } \\
\text { Produk }\end{array}$ & $\begin{array}{l}\text { Produk yang dapat } \\
\text { digunakan dengan mudah }\end{array}$ \\
\hline Fasilitas Fitur & Free Chat \\
\hline Fitur Tambahan & Game \\
\hline $\begin{array}{l}\text { Desain sesuai } \\
\text { kebutuhan } \\
\text { pelanggan }\end{array}$ & $\begin{array}{l}\text { Memiliki tampilan yang } \\
\text { menarik }\end{array}$ \\
\hline \multicolumn{2}{|l|}{\begin{tabular}{l} 
Sumber: pengolahan data kuesioner \\
\hline
\end{tabular}}
\end{tabular}

Tabel diatas menunjukan bahwa dalam memilih social messenger responden menginginkan social messenger dengan tingkat kualitas produk yaitu produk yang dapat digunakan dengan mudah, fasiltas fitur yaitu free chat, fitur tambahan yaitu game dan desain sesuai kebutuhan pelanggan yaitu memiliki tampilan yang menarik

\section{KESIMPULAN DAN SARAN}

\section{Kesimpulan}

Berdasarkan penelitian yang telah dilakukan oleh penulis dapat ditarik kesimpulan tentang preferensi konsumen dalam penggunaan social messenger di Kota Bandung diurutkan dari tigkat kepentingan tertinggi.

1. Responden Keseluruhan :

a. Atribut yang mempunyai nilai kepentingan tertinggi hingga terendah adalah :

1. Fasilitas Fitur

2. Fitur Tambahan

3. Tingkat Kualitas Produk

4. Desain sesuai kebutuhan Pelanggan

Dalam penelitian ini, dapat diketahui pula preferensi atas setiap level di masing-masing atribut. Dengan melihat nilai utilitasnya atau dengan istilah lain angka part worth. Untuk fasilitas fitur responden cenderung lebih menyukai free chat dengan nilai utilitas 0.603 . Fitur tambahan responden cenderung lebih menyukai game dengan nilai utilitas 0.130 . tingkat kualitas produk responden cenderung lebih menyukai produk yang dapat digunakan dengan mudah dengan nilai utilitas 0.200 dan desain sesuai kebutuhan pelanggan responden cenderung lebih menyukai produk yang memiliki tapilan yang menarik.

\section{Saran}

Setiap konsumen mempunyai hak untuk dapat memilih dalam menggunakan social messenger yang mereka sukai, apabila konsumen tidak suka dengan satu social messenger maka konsumen berhak untuk mengguna social messenger yang lain dengan mengevaluasi atribut-atribut mana yang tepat dan kurang tepat untuk konsumen. Keadaan ini menuntut perusahaan untuk selalu melakukan inovasi disetiap layanan yang akan mereka berikan kepada konsumen.

1. Aspek Praktis

a. Berdasarkan hasil dari penelitian ini adalah bahwa fasilitas fitur menjadi preferensi utama konsumen dalam memilih social messenger. Oleh karena itu, strategi penerapan fasilitas fitur harus lebih di optimalkan oleh para pengembang aplikasi. 
cial messenger. Oleh karena itu, sebaiknya para pengembang aplikasi social messenger lebih berinovasi pada fitur tambahan game yang akan ditawarkan pada konsumen. c. Tingkat kualitas produk menjadi preferensi ke tiga bagi konsumen dalam memilih social messenger. Oleh karena itu penerapan tingkat kualitas produk lebih di optimalkan oleh para pengembang aplikasi

d. Desain sesuai kebutuhan pelanggan dengan memiliki tampilan yang menarik menjadi preferensi konsumen dalam memilih social messsenger. Oleh karena itu strategi penerapan tampilan pada social messenger lebih dikembangkan oleh para pengembang aplikasi social messenger.

\section{Aspek Teoritis}

a. Penelitian ini perlu dilakukan pada sampel yang lebih besar dan mencakup kota-kota lainnya dengan variasi responden yang lebih unik. Sehingga didapatkan hasil penelitian yang lebih mendekati realita.

b. Perlu dilakukan penelitian mengenai preferensi konsumen dengan penciptaan profil bagi responden dengan ciri tertentu yang tidak dibahas dalam penelitian ini.

c. Perlu dilakukan penelitian lain yang tidak hanya membahas peferensi konsumen, namun juga membahas faktor-faktor lain yang menjadi pertimbangan konsumen dalam memilih social messenger.

\section{DAFTAR PUSTAKA}

Arikunto, Suharsimi. (2010). Prosedur Penelitian : Suatu Pendekatan Praktik. Jakarta: Rineka Cipta .

amazingbandung.com/2011/12/02/societeit-concordia-gedung-sosialita-yang terlupakan/(diakses pada 17 Februari2014).

apjii.or.id/v2/read/article/apjii-atmedia/134.html (diakses pada tanggal 13 Februari 2014)

Darnius, Rifalin, Delusta, Purba, Open dan Pasukat Sembiring. 2013. Analisis Preferensi Mahasiswa FMIPA USU terhadap Produk Handphone dengan Menggunakan Analiis Konjoin. Vol. 1 No.2 Hal 187-197: Universitas Sumatera Utara

Frank, Robert H. (2011). Microeconomics and Behavior. Eighth edition, Mc.Graw. Hill International Edition

Ghozali, Imam. (2013). Aplikasi Analisis Multivariat dengan Program IBM SPSS 21 (edisi ketujuh). Semarang:Universitas Diponegoro.

Hair .F Joseph, Black C William, Babin J Barry, Anderson E Rolph (2010). Multivariate data analysis: Global perspective, 7 th edition.

Head, Milena, dan Natalia Ziolkowski.2010. Understanding Student Attitudes of Mobile Phone Aplication and Tools : A Study Using Conjoint, Cluster and SEM Analyses. Jurnal Eropa: McMaster University

inet.detik.com/read/2013/04/22/151050/22 27072/398/kakaotalk-bicara-soalpersaingan-dengan-line--wechat (diakses pada tanggal 13 Februari 2014)

Jabir Ali, Sanjev Kapoor, Janakiraman Morthy.2010. Buying behavior of consumer for a food product in an emerging economy: Retrieved from Emerald Journal

jagatreview.com/2014/01/tahun-2013-aplikasi-instant-messaging-mobile-jadiprimadona/(di akses pada tanggal 13 Februari 2014).

Kharisma, Ryandra, Arya. 2012. Analisis Preerensi Konsumen terhadap Multiatribut Produk Film (Studi kasus : Konsumen pengunjung Bioskop Cinem XXI). Vol. 1 No. 2 Hal 120: Universitas Indonesia

Kotler, Philip \& Keller, L. Kevin. (2012). Marketing Management. USA: PT.Pearson Edition. Kotler, Philip \& Keller, L. Kevin. (2009). Manajemen Pemasaran. Ed- 


\section{JURNAL \\ MANAJEMEN \\ INDONESIA}

Vol. 14. No. 2

Agustus 2014 isi 13, Jilid 1. Jakarta: Pearson Education, Inc.

Kotler, Philip \& Keller, L. Kevin. (2007). Manajemen Pemasaran. Edisi 12, Jilid 1 dan 2. Jakarta: Pearson Education, Inc.

Kotler, Philip dan Amstrong, Gary. (2008). Prinsip-Prinsip Pemasaran. Edisi 12, Jilid 1. Jakarta : Erlangga.

LC Koo, Fedrick K C Tao, John HC Yeung. Preferential segmentation of restaurant attributes through conjoint analiysist: : Retrieved from Emrald Journal

Martono, Nanang. (2010). Metode Penelitian Kuantitatif: Analisis Isi dan Analisis Data Sekunder. Edisi 1, Jilid 1. Jakarta: Rajawali Pers

Mothersbaugh, Hawkins. (2010). Consumer Behavior, Building Marketing Strategy. Eleventh edition,Mc.Graw.Hill International Edition.

Ongsono. (2012). Tujuh Kota Terbanyak Penduduknya di Indonesia. (online) http:// www.ongsono.com/go/dfbd75bb8f662a21 ccb43624f8c7dd08/tujuh-kotaterbanyak-penduduknya-diindonesia.html (diakses pada tanggal 17 Februari 2014).

Rangkuti, Freddy. (2011). Riset Pemasaran. Jakarta: PT. Gramedia Pustaka Utama.

Rosipah, Siti, Umi Purwandari. 2013. Preferensi Konsumen Terhadap Pancake dari Tepung Sukun. Vol. 7 No. 1 Hal 53-58: Universitas Trunojoyo Madura

Saunders, Mark, Lewis, Philip and Thornhill, Adrian. (2009). Research Methods for business student. Edisi kelima.

Schiffman, Leon and Leslie Lazar Kanuk (2009). Perilaku Konsumen, Edisi ketujuh.

Sedermayanti dan Syarifudin, Hidayat. (2011). Metodologi Penelitian. Bandung, CV Mandar Maju.

Sekaran, Uma and Bougie, Roger. (2010). Research Methods for Busines.

Sugiyono. (2012). Metode Penelitian Kuantitatif, Kualitatif, dan R\&D. Bandung: Alfabeta.

Tamara, M kharisma, Putra. 2013 Analisis Preferensi Konsumen terhadap smartphone Samsung Bersistem Operasi Android di Kota Bandung: Universitas Telkom

tekno.liputan6.com/read/2016369/pengguna-kakaotalk-di-tanah-air-capai16-juta (diakses pada tanggal 13 Februari 2014) techno.okezone.com/ $\mathrm{read} / 2014 / 01 / 03 / 325 / 921028 /$ pertarungan-sengit-aplikasiolah-pesan-di-2014 (diakses pada tanggal 7 Februari 2014)

tempo.co/read/news/2013/11/25/0725323 93/LINE-Targetkan-500-JutaPengguna-Tahun-2014 (diakses pada tanggal 13 Februari 2014)

trenologi.com/2013122029890/infodigiwhatsapp-populer-tetapi-bbm-palingbanyak-diperbincangkan/ (diakses pada 13 Februari 2014)

teknologi.news.viva.co.id/news/read/2270 75-usia-dominan-pengguna-internet-diindonesia (diakses pada tanggal 17 Juni 2014)

wechat.com/id/features.html\#facebook (diakses pada tanggal 13 Februari2014)

William G, Zikmund (2010). Bussiness Research Methods : South-Western College Pub; 8 th edition.

Wilhelm, Wendy Bryce. 2012. Encouraging Sustainable Consumption through Product Lifetime Extention: The Cae of Mobile Phone. Jurnal USA: Western Washington University 
